\title{
SOSIALISASI MITIGASI BENCANA TSUNAMI TINGKAT SEKOLAH DASAR DI SDN 06, ACEH BARAT
}

\author{
Nabila Hilmy Zhafira ${ }^{1}$, Yusnaidi ${ }^{2}$, Yenny Ertika ${ }^{3}$, Okta Rabiana Risma $^{4}$, Chairiyaton ${ }^{5}$ \\ ${ }^{1,2,5)}$ Program Studi Manajemen, Fakultas Ekonomi, Universitas Teuku Umar \\ ${ }^{3,4)}$ Program Studi Ekonomi Pembangunan, Fakultas Ekonomi, Universitas Teuku Umar \\ e-mail: nabilahilmyzhafira@utu.ac.id
}

\begin{abstract}
Abstrak
Sasaran dalam sosialisasi ini adalah siswa tingkat sekolah dasar, khususnya siswa SDN 06 Kecamatan Johan Pahlawan Kabupaten Aceh Barat, untuk meningkatkan pemahaman dan kesadaran mereka akan bencana. Melalui manajemen resiko yang komprehensif dampak bencana dapat diminimalisir dengan adanya pengetahuan dan wawasan terlebih dahulu. Materi dan video dokumenter yang disampaikan saat sosialisasi berisi informasi yang berupaya ditanamkan agar para siswa sekolah dasar memiliki persiapan diri dan mengetahui langkah awal yang harus dilakukan ketika terjadi bencana. Kuesioner pun digunakan untuk mengukur pemahaman mereka terkait pengetahuan tentang bencana, rencana kegiatan dari bencana, peringatan bencana, dan mobilisasi sumberdaya. Setelah mengikuti sosialisasi siswa dapat mengetahui mana tindakan yang boleh dan tidak boleh dilakukan di lingkungan agar tidak merugikan diri sendiri dan orang disekitar yang kemudian dapat menimbulkan bencana, secara aktif mengambil langkah tepat dan menjadi lebih siaga saat terjadi bencana, serta dapat memanfaatkan pengetahuan semaksimal mungkin sehingga dapat membantu diri sendiri dan orang sekitar saat terjadi bencana
\end{abstract}

Kata kunci: Mitigasi Bencana, Sekolah Dasar, Pencegahan

\begin{abstract}
The target of this socialization is elementary school level students, especially students of SDN 06 Johan Pahlawan, West Aceh, to increase their understanding and awareness of disasters. Through comprehensive risk management, the impact of disasters can be minimized with prior knowledge and insight. The documentary material and video delivered during the socialization contained information that attempted to be instilled so that elementary school students had self-preparation and knew the first steps to take when a disaster occurred. Questionnaires were used to measure their understanding of knowledge about disasters, disaster action plans, disaster warnings, and resource mobilization. After participating in the socialization students can find out which actions are allowed and shouldn't be done in the environment so as not to harm themselves and those around them which can then cause disasters, actively take appropriate steps and be more alert when a disaster occurs, and can make the most of their knowledge so that can help yourself and those around you when a disaster occurs.
\end{abstract}

Keywords: Disaster Mitigation, Primary Schools, Prevention

\section{PENDAHULUAN}

Minimnya pengetahuan mengenai penyebab tsunami menjadi salah satu penyebab banyaknya korban jiwa pada saat bencana tersebut terjadi di Indonesia khususnya Nanggroe Aceh Darussalam. Dengan minimnya informasi dan pengetahuan, masyarakat yang seharusnya menyelamatkan diri sebelum kejadian malah berbondong-bondong menuju kearah pantai untuk menyaksikan fenomena air laut yang surut. Hal ini menyadarkan kita akan perlunya edukasi kebencanaan untuk mencegah resiko lebih besar yang mungkin ditimbulkan di masa mendatang serta untuk dapat mengurangi jumlah korban jiwa akibat sebuah bencana. Diperlukan adanya perubahan paradigma pada masyarakat dari sekedar tanggap darurat menjadi siaga bencana (BNPB, 2017). Bencana bukanlah suatu hal yang diterima begitu saja, namun masyarakat perlu melakukan antisipasi agar dapat meminimalisir dampak dan korban jiwa. 
Badan Nasional Penanggulangan Bencana (BNPB) sebagai salah satu upaya pengurangan risiko bencana telah mengeluarkan buku saku yang secara lengkap memaparkan prosedur menghadapi berbagai bencana bagi masyarakat. Namun, hal tersebut tidak cukup jika hanya ditulis maka kesiagaan melalui pendidikan dan pelatihan menjadi bagian dasar dari upaya pencegahan. Kesadaran masyarakat (Awareness) merupakan upaya kesiapan atau kehati-hatian maka dengan memasyarakatkan persiapan kita mempersiapkan Persiapan diri mendidik (baskoro, 2016).

Pentingnya edukasi kebencanaan ialah untuk membuka pemahaman terhadap informasi kebencanaan yang dapat diperoleh, masyarakat yang mulai memahami akan memiliki semangat responsif dan dapat memotivasi untuk bersama-sama siaga dan melakukan langkah-langkah antisipasi bencana yang kemudian dapat memunculkan rasa tanggung jawab sosial bersama yang bersifat tulus tanpa pembedaan strata sosial.

Korban jiwa akibat suatu bencana merupakan konsekuensi yang tidak dapat diabaikan, dan anak-anak merupakan salah satu kelompok rentan yang membutuhkan dukungan khusus. 60 persen korban bencana alam adalah anak-anak(United Nation International Strategy for Disaster). Sendai Framework for Disaster Risk Reduction 2015-2030 menyatakan bahwa anak-anak bukanlah manusia yang hanya bisa pasrah tak berdaya terpapar bencana alam, karena mereka memiliki potensi untuk menyesuaikan diri terhadap bencana. Salah satu cara untuk memberikan pemahaman terhadap kebencanaan dapat dilakukan melalui pembelajaran yang terintegrasi dalam beberapa mata pelajaran (Rusilowati et al, 2012). Indonesia dapat bercermin pada negara-negara lain yang memiliki tingkat kewaspadaan bencana (emergency preparedness) cukup tinggi, misalnya Jepang dan Filipina. Pendidikan kebencanaan sudah diterapkan sejak di bangku sekolah dan masuk kedalam kurikulum nasional.

Bencana alam tergolong dalam bencana tipe rapid onset, yaitu kejadian yang berlangsung dengan cepat. Selain itu, bukti historis menunjukkan bahwa tsunami mungkin saja terjadi lagi di masa mendatang. Kerugian secara ekonomi pun tidak bisa diabaikan, bahkan pada bencana gempa dan tsunami di Indonesia tercatat kerugian yang lebih besar dibandingkan Negara lain (Gerintya, S, 2018). Hal ini menegaskan kembali perlunya antisipasi bencana serta manajemen resiko yang komprehensif bukan serta merta untuk menghilangkan dampak bencana, namun pentingnya membahas hal ini ialah agar dapat meminimalisir dampak yg ditimbullkan dari bencana itu sendiri dengan adanya pengetahuan dan wawasan terlebih dahulu.

\section{METODE}

Kegiatan ini dilakukan dengan cara sosialisasi, penyebaran kuesioner, dan diskusi interaktif melalui media audio dan video. Pada tahap pertama, sosialisasi diawali dengan pengisian kuesioner sebagai alat observasi awal pemahaman siswa terhadap kebencanaan. Pengisian kuesioner dikhususkan untuk siswa kelas V dan VI yang berjumlah 46 orang, dengan pertimbangan tingkat pemahaman mereka relatif lebih baik dibandingkan siswa kelas I sampai kelas IV. Kuesioner tersebut berisi 35 pertanyaan yang digunakan untuk mengukur pemahaman seputar mitigasi bencana yang terbagi kedalam beberapa kategori yaitu : pengetahuan tentang bencana, rencana kegiatan dari bencana, peringatan bencana, dan mobilisasi sumberdaya.

Setelah melakukan pengisian kuesioner, selanjutnya siswa menyaksikan video kartun dokumenter yang berjudul "Bagaimana Cara Menghadapi Bencana, Baik Gempa Bumi Maupun Tsunami". Video ini dibagi menjadi dua sesi, video dokumenter pertama berdurasi 10 menit dengan tema "Persiapan Menghadapi Bencana Gempa Bumi", kemudian dilanjutkan dengan video dokumenter kedua berdurasi 15 menit dengan tema "Persiapan Menghadapi Bencana Tsunami". Pemilihan media video ini bertujuan agar informasi dapat lebih mudah diterima dan lebih menyenangkan bagi siswa usia sekolah dasar. Para siswa menunjukkan ketertarikan terhadap video dokumenter yang ditampilkan, mereka terlihat sangat antusias mengikuti alur cerita yang ditampilkan pada video tersebut dan memberikan respon terhadap tingkah pemeran pada video tersebut.

Tahap terakhir dari kegiatan ini adalah dengan melakukan diskusi interaktif antara tim pemateri dengan para audiens (siswa Sekolah Dasar Negeri 06) untuk mengukur pemahaman audiens. Diskusi interaktif dilakukan dengan variasi pertanyaan yang berkaitan dengan macammacam bencana, cara menghadapi bencana, dan apa yang perlu dilakukan setelah terjadi bencana. Pada tahap ini pengetahuan para siswa dapat dinilai dari jawaban yang mereka berikan. Selain 
memberikan pertanyaan, siswa juga diminta untuk menceritakan kembali isi video dokumenter tersebut.

\section{HASIL DAN PEMBAHASAN}

Kegiatan pengabdian ini bertujuan untuk memberikan pemahaman dan meningkatkan kesadaran terhadap bencana, maka materi sosialisasi berisi persiapan diri dan langkah awal yang harus dilakukan masyarakat ketika terjadi bencana, diantaranya ialah mengenal tanda-tanda bencana dan tindakan yang harus dilakukan. Materi di paparkan secara sederhana agar mudah di mengerti dan di pahami oleh siswa tingkat sekolah dasar. Setelah pemberian materi melalui media presentasi kemudian dilanjutkan dengan video kartun dokumenter dengan tujuan agar informasi dapat lebih mudah diterima dan lebih menyenangkan bagi siswa usia sekolah dasar. Adapun luaran yang dihasilkan dari kegiatan pengabdian masyarakat ini adalah konsep-konsep dasar kesiapan dalam menghadapi bencana untuk siswa tingkat sekolah dasar, maka pada tahap akhir dilakukan diskusi interaktif antara tim pemateri (dosen) dengan para audiens (siswa Sekolah Dasar Negeri 06) yang bersifat reviu atas materi video yang telah ditonton sebelumnya dan memberikan tanyajawab langsung seputar materi untuk mengukur sejauh mana penyerapan materi yang telah disampaikan.

Setelah mengikuti sosialisasi dengan pokok pembahasan mengenai mitigasi bencana, diharapkan siswa SD 06 Meulaboh mampu:

1) Memilah mana tindakan yang boleh dan tidak boleh dilakukan di lingkungan agar tidak merugikan diri sendiri dan orang disekitar yang kemudian dapat menimbulkan bencana.

2) Secara aktif mengambil langkah tepat dan menjadi lebih siaga saat terjadi bencana.

3) Memanfaatkan pengetahuan semaksimal mungkin sehingga dapat membantu diri sendiri dan orang sekitar saat terjadi bencana.

\section{SIMPULAN}

Pengetahuan mengenai mitigasi bencana yang komprehensif merupakan hal yang perlu dipelajari apabila kita ingin mengurangi dampak serupa bagi bencana di masa depan. Peningkatan tanggungjawab, partisipasi, kemampuan antisipasi dan penanganan bencana dapat dicapai salah satunya melalui pendidikan kebencanaan. Melalui pendidikan bencana bukan serta merta dapat menghilangkan dampak bencana, namun pentingnya membahas hal ini ialah agar dapat meminimalisir dampak yg ditimbullkan dari bencana itu sendiri dengan adanya pengetahuan dan wawasan terlebih dahulu.

Dengan memiliki pemahaman dan kesiapan mengenai mitigasi bencana secara dini, tentunya anak-anak dapat mengetahui langkah-langkah yang harus dilakukan saat terjadi bencana. Pemahaman tersebut dapat meningkatkan kepekaan dan partisipasi siswa/i terhadap situasi serta kondisi saat bencana terjadi dan meminimalisir kepanikan serta trauma yang mungkin ditimbulkan

\section{SARAN}

Pengenalan dan pemahaman mengenai mitigasi bencana perlu dilakukan mengingat manfaat positif yang diperoleh demi meningkatkan kesiapsiagaan masyarakat dalam menghadapi bencana yang tidak dapat dipastikan kemunculannya. Pengenalan difokuskan pada masyarakat Meulaboh khususnya usia sekolah dasar dengan tujuan agar dapat meningkatkan kesiapsiagaan sedari dini. Meningkatnya pengetahuan melalui sosialisasi dan pemberian pelatihan kebencanaan dapat menjadikan masyarakat lebih waspada saat menghadapi bencana. Kegiatan serupa dapat dilakukan kembali dengan khalayak sasaran yang lebih luas, mengingat banyaknya anak usia sekolah dasar yang belum memahami dan belum pernah mendapatkan informasi mengenai langkah-langkah mitigasi bencana. Diharapkan agar kegiatan lainnya dapat mengeksplorasi lebih mendalam tentang kesiapsiagaan dalam menghadapi bencana, agar masyarakat dapat menjadi lebih siap dan dapat mengurangi jumlah korban jiwa serta trauma yang muncul pasca bencana.

\section{DAFTAR PUSTAKA}

Ajuba, P. B. (2015). Studi Kebijakan Mitigasi Bencana Gunung Api Berbasis Kearifan Lingkungan Di Sdn Ngablak Srumbung Magelang. Universitas Negeri Yogyakarta. 
Baskoro, f. m. (2016, desember 15). Wapres: Indonesia Butuh Pendidikan Bencana Alam Seperti Jepang. Retrieved januari 15, 2020, from berita satu: https://www.beritasatu.com/faisal-maliki-baskoro/nasional/404661/wapresindonesia-butuh-pendidikan-bencana-alam-seperti-jepang

BNPB. (2017). Badan Nasional Penanggulangan Bencana. Retrieved oktober 2018, from https://www.bnpb.go.id/

Gerintya, S. (2018, Oktober 2). Gempa dan Tsunami: Mitigasi Buruk, Kerugian Tinggi. Retrieved desember 2018, from tirto.id: https://tirto.id/gempa-dan-tsunamimitigasi-buruk-kerugian-tinggi-c31k

Rusilowati, A., Supriyadi, Binadja, A., \& Mulyani. (2012). Mitigasi Bencana Alam Berbasis Pembelajaran Bervisi Science Environment Technology And Society. Jurnal pendidikan fisika indonesia. 